\title{
Lignocellulosic agroindustrial waste in Peru: potential for bioethanol, energy, and reduction of $\mathrm{CO}_{2}$ emission
}

\author{
Patricia Retto-Hernandez, B.Sc루 Meliza Lindsay Rojas, Dr. ${ }^{2,}$; Leslie Lescano, M.Sc. ${ }^{1}$; Jesús Sanchez-Gonzalez, \\ M.Sc. ${ }^{1}$; Guillermo Linares, Dr. ${ }^{1}$ \\ ${ }^{1}$ Department of Agroindustrial Sciences, School of Agroindustrial Engineering, Universidad Nacional de Trujillo (UNT), Trujillo, \\ Peru,patyretto@gmail.com, llescano@unitru.edu.pe, jsanchezg@unitru.edu.pe, glinares@unitru.edu.pe. \\ ${ }^{2}$ Dirección de Investigación y Desarrollo, Universidad Privada del Norte, Trujillo, Peru, meliza.rojas@upn.edu.pe \\ * corresponding author: meliza.rojas@upn.edu.pe; Av. Del Ejército 920, Trujillo, Peru.
}

\begin{abstract}
The residues from agricultural and agroindustrial activities are not adequately valorised and at best they are destined for animal consumption or else they are inadequately disposed of. The objective of the present work was to estimate and highlight the energy (calorific and electric) potential of second-generation bioethanol production using lignocellulosic waste from the most important crops in Peru. In addition, the reduction of $\mathrm{CO}_{2}$ emissions by using bioethanol produced from those lignocellulosic wastes was estimated. The biomass considered in this study was from the harvest and processing of sugarcane, rice, banana, yellow corn, oil palm and asparagus. It was determined that the annual lignocellulosic biomass availability was $\sim 22$ million tons, from which, $33.03 \%$ correspond to banana waste, $28.56 \%$ correspond to sugarcane waste. The potential of bioethanol production and energy generation was obtained using a theory conversion of cellulose, hemicellulose of each biomass. It was calculated 3.51 million tons of bioethanol/year, which total energy corresponds to 2.16 million toe/year with an electric energy potential of $8.81 \mathrm{GWh} /$ year. This quantity could be enough to supply $9.11 \%$ and the total national energy demand and $0.02 \%$ of the electric energy demand, besides, it could help reduce in about $19.86 \%$ the $\mathrm{CO}_{2}$ emissions.

Keywords-lignocellulosic biomass, agroindustrial crops, second-generation ethanol, energy potential
\end{abstract}

\section{INTRODUCTION}

Petroleum was discovered in the 80's decade and largely supplied by the United States, from the states of Pennsylvania and Texas. The expansion of the supply of oilderived fuels caused them to become inexpensive, becoming one of the main drivers of the industrial era, especially for the production of energy to operate factories and cars Cseke, et al. [1]. However, there are two principal problems related to the use of traditional liquid fuels: they are non-renewable and emit high carbon dioxide $\left(\mathrm{CO}_{2}\right)$ quantity. Carbon dioxide makes up the largest share of the greenhouse gases contributing to global warming and climate change. According to the Carbon Dioxide Information Analysis Center (CDIAC) [2], the $\mathrm{CO}_{2}$ emissions of Latin America \& Caribbean are equivalent to $58.3 \%$ of the total world emissions in 2014. On the one hand, by considering that in the last ten years the $\mathrm{CO}_{2}$ emissions have increased by $24.3 \%$ contributing to the greenhouse effect, acid rain and the alteration of ecosystems. On the other hand, the

Digital Object Identifier (DOI):

http://dx.doi.org/10.18687/LACCEI2020.1.1.463

ISBN: 978-958-52071-4-1 ISSN: 2414-6390 environmental pollution as a consequence of the fossil fuels use coupled with the rapid depletion of them, increases the need to develop alternative and renewable sources of energy [3].

The U.S. Energy Information Administration (EIA) projects that world energy consumption will grow by $28 \%$ between 2015 and 2040 [4], were renewable energy from bio combustibles obtained from renewable sources represent a key source for substitution of petroleum derivates [5]. Nowadays, ethanol of first-generation is being obtained from raw materials destined for human consumption, which contains saccharose or from starch sources. Therefore, the first-generation ethanol production conducted to a hard competency of bio combustible and agri-food industries [6].

Consequently, technological challenges are focused on second-generation bio combustible production, which results from complex to simple sugars conversion [7]. The dominant polymer is discomposed in glucose and xylose, which are two simple monomers used for bioethanol production. Glucose and xylose derivatives from cellulose and hemicellulose which are the principal components of lignocellulosic biomass $[8,9]$. Therefore, any type of biomass could be transformed in bioethanol by using different physical, and biochemical processes [10]. Non-alimentary materials, agroindustrial and agricultural wastes could be used as lignocellulosic sources. It is important to highlight that the second-generation bioethanol is chemically identic to the first-generation ethanol, the difference is only the source and the process to obtain each one [11].

In Peru, renewable energy is one option to guaranty the combustible demand. Despite there is national petroleum production, in the last years, this production presents a decrescent tendency [12]. Therefore, to satisfy the internal demand, Peru imports from EEUU and Brazil principally diesel and gasoline, which are highly used for the transport sector [13].

The concept of biomass as a source of energy generation is not recent, despite this, at present is little the exploitation that has the waste generated by agricultural and agroindustrial processes in the country. However, the Ministry of Energy and Mines (MEM) in the national energy balance 2016 , reported that $10.2 \%$ of the total primary energy production, is prevenient from non-commercial sources, from which the obtained from sugarcane bagasse constitutes $17.14 \%$ with $18,248 \mathrm{TJ}$ [14]. The energy obtained from sugar

18th LACCEI International Multi-Conference for Engineering, Education, and Technology: "Engineering, Integration, and Alliances for a Sustainable Development" "Hemispheric Cooperation for Competitiveness and Prosperity on a Knowledge-Based Economy", July 27-31, 2020, Virtual Edition. 1 
cane bagasse is used by the thermal power plants of the sugar and alcohol industries. Under these scenarios, it is deduced the need to use the biomass sources available in Peru as primary energy sources and to know the theoretical potential that these can provide as inputs for the generation of bioethanol from lignocellulosic biomass.

In this sense, the objective of this study was to calculate the energy (calorific and electric) potential of the production of second-generation bioethanol from agricultural and agroindustrial waste from different biomass, through the theoretical conversion approach of its lignocellulosic components. In addition, the reduction of $\mathrm{CO}_{2}$ emissions by using bioethanol produced from lignocellulosic wastes was estimated.

Furthermore, it is important to mention that the results presented in this study provide theoretical estimates of the intrinsic energy potential of the residues of each crop and can serve as a basis for further studies.

\section{MATERIAL AND METHODS}

\section{A. Selection of the most important crops}

Due to the great diversity of crops that exist in Peru, the Pareto diagram was employed to select the 6 most important crops. The agricultural sub-sector production database of the "Informe de Seguimiento Agroeconómico (ISA)" of the "Sistema Integrado de Estadística Agraria" [15] was used. After identifying the most important crops, the annual available production for the period (2008-2018) was analysed. Different database, such as those provided by "Dirección de Estadística Agraria (DEA)" of the "Ministerio de Agricultura y Riego (MINAGRI)" and by the "Instituto Nacional de Estadística e Informática (INEI)" were used.

\section{B. Principal waste generation from the selected crops}

Once the crops were selected, the production chain with the main transformation processes was evaluated to identify and calculate the generated waste $\left(\% w t_{i j}\right)$. The generated waste was calculated from a balance among percentages of the total crop production, hectares harvested or final product quantity. For that, the results reported in diverse studies were considered (Table I).

\section{Lignocellulosic biomass determination}

To calculate the total cellulose (Cse, (1)) and hemicellulose (Hse, (2)) for each crop, the lignocellulosic compounds percentage was identified by tacking account the crop type and several references related to lignocellulosic waste recovery or those that studied the full composition of the crop (Table I).

$$
\begin{aligned}
& \text { Cse }\left[\frac{\text { ton }}{\text { year }}\right]=\sum_{i=1}^{n} \sum_{j=1}^{m} m\left[\frac{\text { ton }}{\text { year }}\right]_{i} x \% w t_{i j} x \% \text { Cse }_{i j} \\
& \text { Hse }\left[\frac{\text { ton }}{\text { year }}\right]=\sum_{i=1}^{n} \sum_{j=1}^{m} m\left[\frac{\text { ton }}{\text { year }}\right]_{i} x \% w t_{i j} x \% H s e_{i j}
\end{aligned}
$$

Where $m$ represent the annual production (Fig.3) of each crop selected using the Pareto diagram and, $j$ represent the different agricultural and agroindustrial residues obtained from an " $i$ " crop; $\% w t_{i j}$ is the production percentage of a " $j$ " residue of an " $i$ " crop; $\% C s e_{i j}$ and $\% H s e_{i j}$ are the mass percentage of the cellulose and hemicellulose content, respectively of a " $j$ " residue of an " $i$ " crop.

\section{Potential of bioethanol production}

The potential of bioethanol production from residual biomass was calculated according to the method described by Goh, et al. [8], which was described in Fig. 1.

Considering the stoichiometric conversion performance, the recovery (crecovery) and fermentation ( $\varepsilon$ fermentation) efficiency factors, the bioethanol potential can be calculated from the following equations.

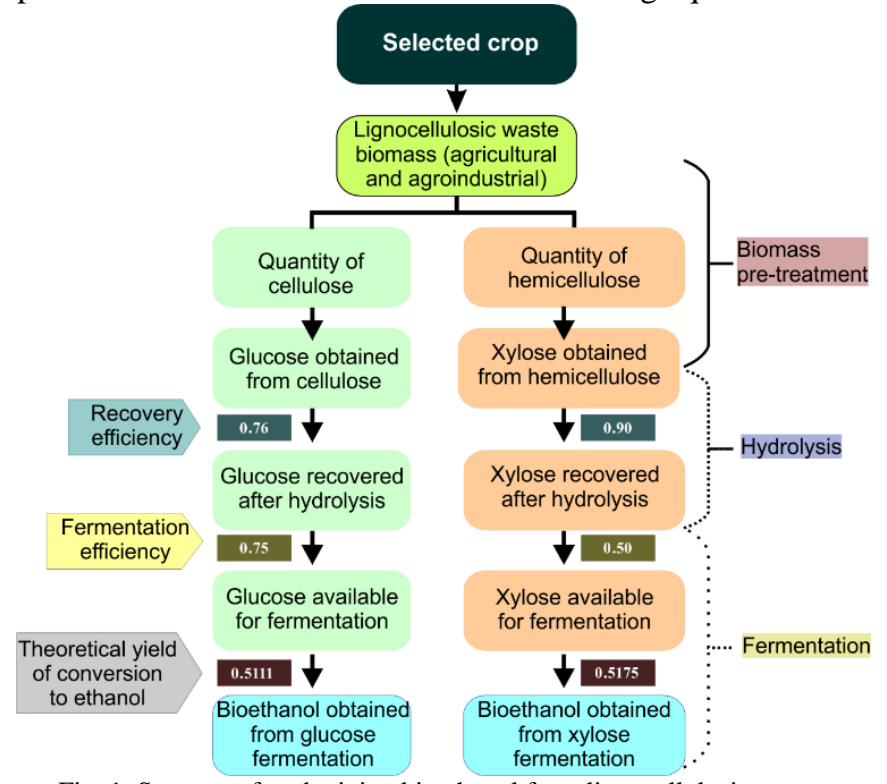

Fig. 1. Sequence for obtaining bioethanol from lignocellulosic waste biomass.

\section{Bioethanol from cellulose}

Gse $_{f}\left[\frac{\text { ton }}{\text { year }}\right]=$ Cse $\left[\frac{\text { ton }}{\text { year }}\right] x$ E recovery $x$ \& fermentation
BioEtOH obtained from Gse $\left[\frac{\text { ton }}{\text { year }}\right]=G s e_{f}\left[\frac{\text { ton }}{\text { year }}\right] \times B c G$

Where Gse is the glucose, Gse $e_{f}$ is the glucose available for fermentation, $C s e$ is the cellulose from lignocellulosic waste, $B c G$ is the bioethanol conversion yield from glucose.

\section{Bioethanol from hemicellulose}

$$
\begin{aligned}
& X_{\text {se }}\left[\frac{\text { ton }}{\text { year }}\right]=\text { Hse }\left[\frac{\text { ton }}{\text { year }}\right] x \text { E recovery } x \text { E fermentation } \\
& \text { BioEtOH from Xse }\left[\frac{\text { ton }}{\text { year }}\right]=X s e_{f}\left[\frac{\text { tn }}{\text { year }}\right] x B c X
\end{aligned}
$$

Where $X s e$ is the xylose, $X s e_{f}$ is the xylose available for 
fermentation, Hse is the hemicellulose from lignocellulosic waste, $B c X$ is the bioethanol conversion yield from xylose.

\section{Total bioethanol potential}

Finally, the total ethanol potential was considered as the sum of the results of both components obtained in equations (4) and (6):

$\dot{m}_{\text {bioEtoH }}\left[\frac{\text { ton }}{\text { year }}\right]=$ Gse bioEtOH + Xse bioEtOH

\section{E. Energy potential of bioethanol}

\section{Calorific energy potential calculi}

For the energy potential of the bioethanol $\left(\dot{Q E_{\text {bioEtoH }}}\right)$, firstly it was determined the ton of oil equivalent (toe), by considering that one ton of bioethanol is equivalent to 0.617 toe [16].

One toe is a unit of energy defined as the amount of energy released by burning one ton of crude oil [17], that is: 1 toe $=10^{7} \mathrm{kcal}=41.868 \mathrm{GJ}$. Obtaining the equation (8).

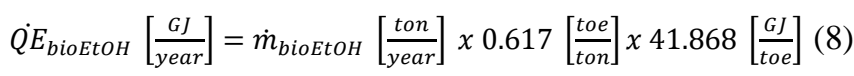

\section{Electric energy potential calculi}

The potential for electric energy generation from bioethanol $\left(\dot{E} E_{\text {bioEtOH }}\right)$, was calculated considering the equivalency of $1 \mathrm{kWh}=3.6 \mathrm{MJ}$, according to the equation:

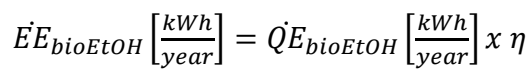

Where $Q E_{\text {bioEtoH }}$ is energy potential of the bioethanol per year in $\mathrm{kWh}$ and $\eta$ is the global efficiency of bioethanol conversion to electric energy. The $\eta$ value was considered $35 \%$, which is the electrical yield if the bioethanol produced is burned as fuel in a power generation plant [18].

\section{F. Reduction of CO2 emissions by using bioethanol produced from lignocellulosic wastes \\ The quantity of $\mathrm{CO}_{2} \quad\left(\dot{\mathrm{m}}_{\mathrm{CO}_{2}}\right)$ emissions to the} environment which could be avoided if all the potential bioethanol produced from lignocellulosic biomass is used, was calculated according to equation (8). Equivalences reported by Henao, et al. [19], were used. Where 1 ton of petroleum emits 7.14 tons of $\mathrm{CO}_{2}$, and 1 ton of bioethanol fuel emits 0.956 tons of $\mathrm{CO}_{2}$.

$\dot{m}_{\mathrm{CO}_{2}}\left(\frac{\text { ton }}{\text { year }}\right)=$ toe $($ ton $) \times 7.14-$ ton $_{\text {bioEtOH }} \times 0.956$

\section{RESULTS AND DISCUSSION}

\section{A. Selection of the most important crops}

By using the Pareto analyses (Fig. 2), from 40 crops it was selected 6 representative crops: sugarcane, rice, banana, yellow corn, oil palm and asparagus, which represent the $80 \%$ of the agricultural production. Crops representing a production lower than $0.5 \%$ were not presented.

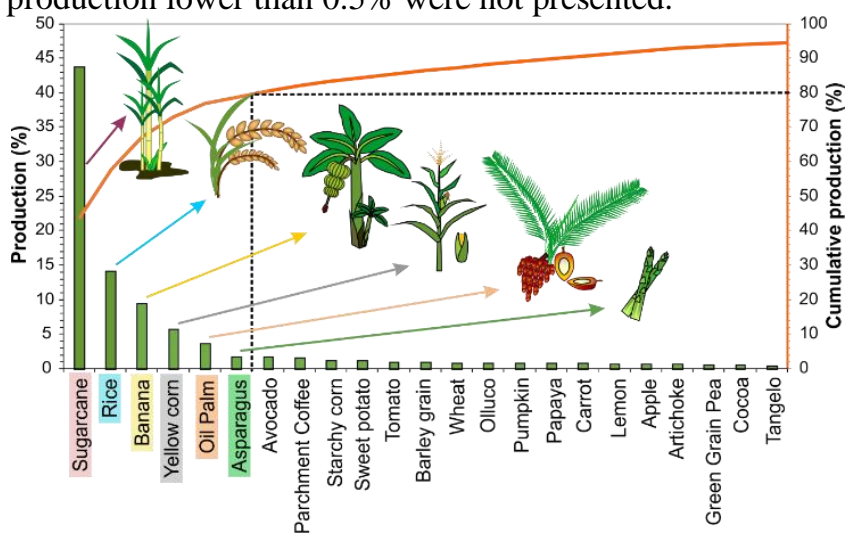

Fig. 2. Pareto diagram for representative crop selection, based on report data of SIEA [15]. And the schematic representation of the selected crops.

For each selected crop it was analysed their agroproductive chain (from the harvest until industrialized product) obtaining the different biomass types. It is important to mention that the annual production of biomass was approximated according to the calculi method used for each crop, which was explained in the correspondent sections.

\section{B. Selected crops production trends}

In Fig. 3 the trends of production of the 6 previously selected crops were presented, a large difference in sugarcane production with respect to others was evidenced along the period.

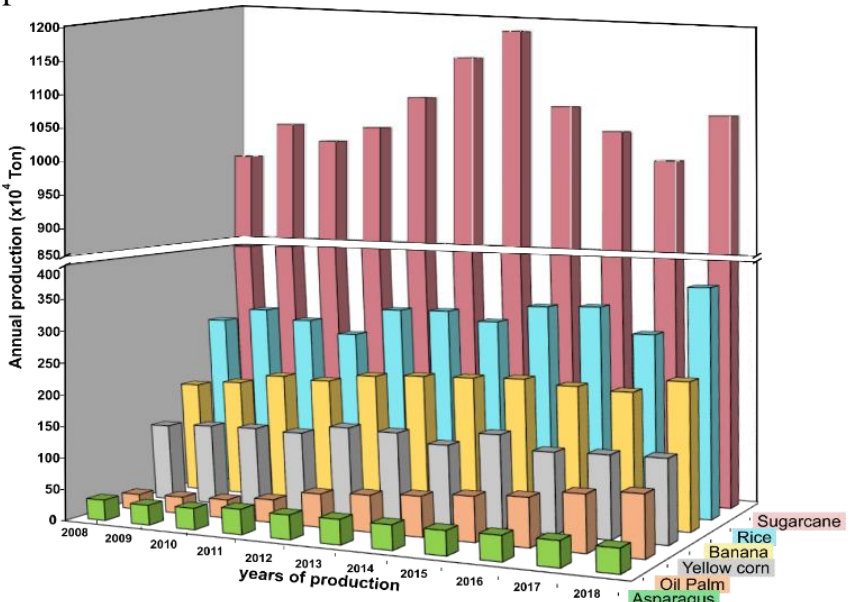

Fig. 3. Annual production of each selected crop from 2008 to 2018. Data from [20].

The sugarcane production industry has been experiencing various stages of growth and contraction, due to climatic, productive factors, and changes in the regulations of the main sugar-producing companies. Concerning the national sugarcane production, the area harvested increased with an 
annual average rate of $2.03 \%$, this is mainly due to the higher consumption of derivatives of this crop, such as blond and white sugar, as well as the production of ethanol.

Rice production has been growing where the harvest area has an average annual growth rate of $2.25 \%$, the largest area harvested was in 2018. This growth is due to the greater harvested areas and the favourable climate that allowed the good development of this cereal. The main producing Peruvian regions of husk rice are: San Martín, Piura, Lambayeque, La Libertad, Arequipa and Amazonas mainly, being the San Martin region the one that presents the highest production of husk rice representing $22.52 \%$ of the national production, in second place is La Libertad, with a production, in the same year, of 362 thousand tons, representing $12.62 \%$ of the annual total [21].

The banana growing has a great economic and social importance in Peru, in addition to being one of the foods of great importance for the food diet in the country [22]. In commercial terms, bananas are growing steadily every day, strengthened since the signing of the "Acuerdo de Ginebra del Banano" in March 2013 that opened a Free Tread Agreement (FTA) with the European Union [23] expanding the export market of this fruit. Thus, as of December 2018, the value of shipments was 166 million soles, $13 \%$ higher than in 2017 with 148.5 million [24].

The yellow corn is the fourth most important crop nationwide. It also represents a great relevance because it is part of the poultry and pig production chain, which are important in terms of economic and social activity for the country [25]. Likewise, it is expected that yellow corn production will continue with a sustained growth in the coming years, in addition to being one of the objectives of the National Agricultural Innovation Program in Corn of the INIA (PNIA), that is, contributing to the increase in productivity and production of the yellow corn crop to meet national demand [26].

Oil palm is a crop native to West Africa and nowadays it is spread in the tropical areas of the world. This crop has been accentuated in the Amazon, in four specific regions Ucayali, San Martín, Loreto and Huánuco [21]. In Peru, a greater dynamism was observed from 1900 with the support of international organizations that promoted palm agroindustry with small and medium producers [27].

Asparagus cultivation began in Peru in 1950, mainly accentuated on the northern coast of the La Libertad region, being the region where $50 \%$ of the national production is currently processed, followed by Ica (39\%) and Lima (5\%). It is important to mention that asparagus is considered a flagship product, such as quinoa, avocado and coffee, and, despite presenting a low level of consumption nationwide $(5 \%)$, it is currently largely demanded by the market international, registering in 2017 an export amount (fresh, canned and frozen) [28].

National perspectives in the agricultural and agribusiness sector, based on the current growth rates of the main trading partners during 2018 [29], suggest a positive impact on the economy in Peru in the short and long term, favouring to a greater extent the agricultural sector. Additionally, according to FAO's agricultural perspectives 2018-2027, it is expected that during the next 10 years for America the production of commodity crops (cereals, corn, sugar, biodiesel, etc.) will rise by $14 \%$ due to high demand and the continued growth of patterns of crops consumption in Latin American countries influenced by factors such as better income and population preferences[30]. With this trend, it is expected that the areas of plantation and the production of sugarcane, rice, banana, yellow corn, oil palm and asparagus will continue to grow in the coming years, which could enhance the use of their crop residues in the sector of renewable energy, contributing to the country's energy sustainability.

\section{Lignocellulosic biomass from agroindustrial waste}

The selected crops produce a large amount of waste throughout their production chain, both agricultural and agroindustrial waste. Based on the literature review (Table I) the different amounts of waste generated by the selected crops have been determined.

In Peru, the activities of the sugarcane, paddy rice, banana, corn, oil palm and asparagus industry generate a considerable amount of non-food waste that is not properly exploited. As shown in Table I, the sugarcane harvest in its state of maturity produces a large amount of usable biomass, where green leaves, dry leaves, shoots, and remaining reeds. On the other hand, in the sugar plants, the bagasse is generated. Regarding rice biomass, the ratio of rice husk and straw, which are residues generated in a typical rice production, were obtained from different sources (Table I). To simplify further calculation, an average of reported values in Table I were taken for the rice husk and straw $\left(\% w t_{i j}\right)$ and also for their cellulose $\left(\% \mathrm{Cs}_{i j}\right)$, hemicellulose $\left(\% H s e_{i j}\right)$ components. Of the residues that are generated during banana growth, the one with the greatest volume is the pseudostems that cover most of the tree and are responsible for the growth of the fruits [31]. In sum, during the development and after the harvest of the banana crop, it leaves four types of agricultural residues: inflorescence waste (rachis), pseudostems, leaves and discarded fruits [32]. On the other hand, Jingura and Matengaifa [33] worked with agricultural biomass of fruit and vegetable crops, based on a product: residue ratio of 1: 2 for fruits and 1: 0.4 for vegetables. From corn plantation, theoretically, only $50 \%$ of the stubble (agricultural waste) generated for incorporation into the soil (stubble and mixed with the farmland) is used as organic matter [34]. Faiguenbaum [35] reported data about the amount of waste generated and the corn production yield. The data was analysed, and a linear behaviour where found waste generated (ton/ha) $=1.1748$ corn crop yield (ton $/$ ha) $\left(\mathrm{R}^{2}>0.99\right)$. In this sense, considering that the average yield of maize production in Peru is 4.38 ton/ha, the theoretical generation of waste is 5.14 tons/ha harvested. Another 
lignocellulosic residue that is generated in the corn processing is the corncob [36].

Regarding the use of oil palm, conventionally palm oil is the extract of the mesocarp and the nucleus of the fruit; leaving a significant amount of waste, which includes: palm leaf residues (frond), logs, mesocarp fibre, kernel shell and empty fruit clusters or bunch [37, 38]. In Asparagus production and processing, there are 2 types of waste obtained, in the first stage the agricultural waste (trunks and foliage of the plant) that are cut before the harvest, the yield of waste generated per hectare is estimated between 50 to 70 ton/ha [39]. The second type of waste is obtained from the asparagus peeling process in the asparagus canning process, known as "peladilla", which constitutes approximately $25 \%$ by weight of the asparagus obtained [40].

In general, the lignocellulosic biomass showed in Table II was calculated by the sum of total cellulose (1) and total hemicellulose (2). For this, it was considered the annual crop production showed in Fig. 3, except for the case of palm oil were the oil production [41] data were also used to calculate the availability of oil palm waste. In addition, for all crops, it was considered the amount of biomass generated $\left(\% w t_{i j}\right)$, the cellulose $\left(\% C s e_{i j}\right)$ and hemicellulose $\left(\% H s e_{i j}\right)$ components of each crop waste (Table I). It was observed that the growth of lignocellulosic biomass generation is proportional to the national production of each raw material used. In general terms, the total biomass generated along the studied period (2008-2018) reached 20.31 Mton, with a growth of $18.17 \%$ in 2018 compared to 2008. Likewise, it is observed that the biomass with the highest representation is that of bananas $(33.03 \%)$, followed by sugarcane biomass $(28.56 \%)$ and rice biomass $(21.34 \%)$ and oil palm, corn and asparagus biomass in a smaller proportion.

TABLE I

PRINCIPAL WASTE (\%) OBTAINED FROM EACH CROP AND THEIR LIGNOCELLULOSIC COMPOSITION

\begin{tabular}{|c|c|c|c|c|c|c|}
\hline \multirow[b]{2}{*}{ Crop “i”" } & \multirow[b]{2}{*}{ Crop waste "j" } & \multirow[b]{2}{*}{$\% w t_{i j}$} & \multirow[b]{2}{*}{ Source } & \multicolumn{2}{|c|}{ Lignocellulosic composition (\%) } & \multirow[b]{2}{*}{ Source } \\
\hline & & & & Cellulose $\left(\% C s e_{i j}\right)$ & Hemicellulose $\left(\% H s e_{i j}\right)$ & \\
\hline \multirow{5}{*}{ Sugarcane } & Bagasse & 30 & {$[42]$} & $46.60 \%$ & $29.40 \%$ & [43] \\
\hline & Green leaves & 13.3 & \multirow[t]{4}{*}[44,45]{} & $45.13 \%$ & $26.00 \%$ & [46] \\
\hline & Dry leaves & 64.2 & & $31.00 \%$ & $24.30 \%$ & \multirow{3}{*}{ [47] } \\
\hline & Shoots & 7.5 & & $42.00 \%$ & $26.00 \%$ & \\
\hline & Remainder sugarcane & 15.0 & & $31.00 \%$ & $22.60 \%$ & \\
\hline \multirow{2}{*}{ Husk rice } & rice husk $(\%)$ & $0.2-0.33$ & \multirow[t]{2}{*}[48-50]{} & $28.6^{\mathrm{a}}-35^{\mathrm{b}}$ & $28.6^{\mathrm{a}}-25^{\mathrm{b}}$ & \multirow[t]{2}{*}{${ }^{\mathrm{a}}[51],{ }^{\mathrm{b}}[52]$} \\
\hline & Rice straw (\%) & $0.4-1.53$ & & $32^{a}-43^{b}$ & $35.7^{\mathrm{a}}-25^{\mathrm{b}}$ & \\
\hline \multirow{3}{*}{$\begin{array}{c}\text { Banana } \\
\text { waste }\end{array}$} & Pseudostem & 300 & \multirow[t]{3}{*}{ [53] } & $26.4^{\mathrm{a}}, 28.4^{\mathrm{b}}, 36.1^{\mathrm{c}}$ & $10.2^{\mathrm{a}}, 7.5^{\mathrm{b}}, 7.0^{\mathrm{c}}$ & \multirow{3}{*}{${ }^{\mathrm{a}}[32] ;{ }^{\mathrm{b}}[54] ;{ }^{\mathrm{c}}[55]$} \\
\hline & Rachis & 15 & & $38.0^{\mathrm{a}}, 37.3^{\mathrm{b}}, 44.3^{\mathrm{c}}$ & $8.7^{\mathrm{a}}, 11.4^{\mathrm{b}}, 22^{\mathrm{c}}$ & \\
\hline & Leaves & 48 & & $21.9^{\mathrm{a}}, 20.4^{\mathrm{b}}, 32.6^{\mathrm{c}}$ & $12.8^{\mathrm{a}}, 8.6^{\mathrm{b}}, 12.0^{\mathrm{c}}$ & \\
\hline \multirow[b]{2}{*}{$\begin{array}{c}\text { Yellow } \\
\text { corn }\end{array}$} & Agricultural waste & 117.5 & [35] & $38.0 \%{ }^{\mathrm{a}}$ & $26.0 \%{ }^{\mathrm{a}}$ & \multirow[b]{2}{*}{${ }^{\mathrm{a}}[56],{ }^{\mathrm{b}}[57],{ }^{\mathrm{c}}[36]$} \\
\hline & Corncob & 12 & {$[36,58]$} & $45.6 \%^{\mathrm{b}}, 40.95 \%^{\mathrm{c}}$ & $36.9 \%^{\mathrm{b}}, 38.94 \%^{\mathrm{c}}$ & \\
\hline \multirow{5}{*}{ Oil Palm } & Oil palm logs and leaves & $3 *$ & [59] & $32.5 \%$ & $36.1 \%$ & \multirow{5}{*}[60,61]{} \\
\hline & Empty fruit clusters & $22 * *$ & [62] & $38.3 \%$ & $35.3 \%$ & \\
\hline & Core shell & $5.5^{* *}$ & & $20.8 \%$ & $22.7 \%$ & \\
\hline & Mesocarp fibre & $13.5^{* *}$ & & $33.9 \%$ & $26.1 \%$ & \\
\hline & Effluent from oil production & 370 & [63] & $11.0 \%$ & $7.0 \%$ & \\
\hline \multirow{2}{*}{ Asparagus } & Asparagus brush & $50-70^{*}$ & [39] & $27.5 \%{ }^{\mathrm{a}}$ & $18.4 \%^{\mathrm{a}}$ & \multirow{2}{*}{${ }^{\mathrm{a}}[64],{ }^{\mathrm{b}}[65]}$. \\
\hline & asparagus peel & 25 & [40] & $34.6 \%{ }^{\mathrm{b}}$ & $21.2 \%^{\mathrm{b}}$ & \\
\hline
\end{tabular}

TABLE II

LIGNOCELLULOSIC WASTE BIOMASS (TON) GENERATED FROM THE PRODUCTION AND PROCESSING OF SELECTED CROPS ( 2008 - 2018).

\begin{tabular}{|l|l|l|l|l|l|l|}
\hline Year & Sugarcane & Rice & Banana & Corn & Oil Palm & Asparagus \\
\hline 2008 & $5,950,774$ & $4,478,750$ & $6,508,329$ & 790,284 & 412,815 & $1,933,248$ \\
\hline 2009 & $6,293,399$ & $4,794,825$ & $6,775,714$ & 817,511 & 445,137 & $1,909,266$ \\
\hline 2010 & $6,118,567$ & $4,538,693$ & $7,286,441$ & 823,721 & 477,651 & $2,004,604$ \\
\hline 2011 & $6,260,459$ & $4,207,006$ & $7,144,025$ & 808,642 & 642,567 & $2,165,178$ \\
\hline 2012 & $6,566,948$ & $4,878,458$ & $7,557,983$ & 893,893 & 864,972 & $2,152,970$ \\
\hline 2013 & $6,961,752$ & $4,883,977$ & $7,676,916$ & 876,097 & 935,816 & $2,192,795$ \\
\hline 2014 & $7,213,424$ & $4,643,271$ & $7,716,796$ & 787,747 & $1,188,841$ & $2,085,105$ \\
\hline 2015 & $6,467,509$ & $5,051,707$ & $7,787,660$ & 923,149 & $1,076,129$ & $2,198,264$ \\
\hline 2016 & $6,227,266$ & $5,074,696$ & $7,528,602$ & 790,841 & $1,189,576$ & $2,088,258$ \\
\hline 2017 & $5,953,091$ & $4,443,676$ & $7,353,291$ & 801,889 & $1,713,845$ & $2,114,294$ \\
\hline 2018 & $6,376,907$ & $5,591,424$ & $8,051,997$ & 806,317 & $1,162,301$ & $1,979,091$ \\
\hline
\end{tabular}

18 $^{\text {th }}$ LACCEI International Multi-Conference for Engineering, Education, and Technology: "Engineering, Integration, and Alliances for a Sustainable Development" "Hemispheric Cooperation for Competitiveness and Prosperity on a Knowledge-Based Economy", 29-31 July 2020, Buenos Aires, Argentina. 5 


\section{Potential of bioethanol production}

Once the cellulose and hemicellulose content were calculated, (4) and (6) were used to determine the bioethanol potential presented in Fig. 4.

\section{Bioethanol from sugarcane biomass}

Considering the total biomass of bagasse obtained in 2018 and considering an average bioethanol density of $0.789 \mathrm{~kg} / \mathrm{L}$, a production yield of $258.84 \mathrm{~L}$ of bioethanol/ton of biomass results. Similar to other studies, from one ton of wet bagasse it is possible to obtain $200 \mathrm{~L}$ of bioethanol [66]. The results depend on various factors from the cane variety, the type of hydrolysis, fermentation, recovery method until distillation method [67]. Velásquez Riascos and López [68] studied the feasibility of a plant for the production of bioethanol from sugarcane harvest wastes, the authors reported a yield of $78.57 \%$, which represents a production of $120.8 \mathrm{~L}$ of bioethanol/ton biomass, a result close to that obtained in the present study. From the results presented in Table II, it was observed that during the last ten years, approximately 70 million tons of lignocellulosic biomass were produced, between agricultural waste and processing (bagasse) waste of sugarcane, which were able to produce 15,909 million $\mathrm{L}$ of bioethanol.

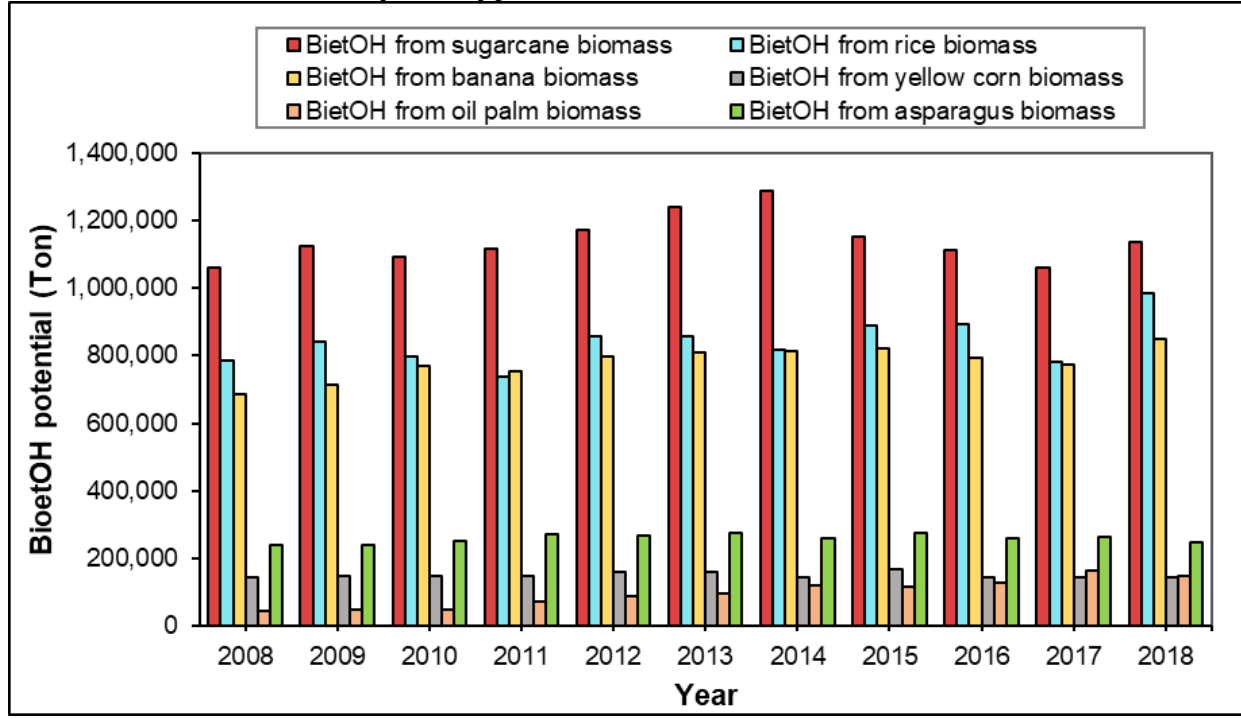

Fig. 4. Bioethanol potential production (for the 2008-2018 period) from sugarcane, banana, oil palm, rice, yellow corn, and asparagus lignocellulosic waste produced by harvesting and processing in Peru.

\section{Bioethanol from rice biomass}

Different studies have been carried out to improve the fermentation process in obtaining bioethanol from rice residues. For example, Capdevila, et al. [69], from pre-treated and hydrolysed rice husk, obtaining a bioethanol production of $8.81 \mathrm{ton} / \mathrm{h}$ with a purity of $65.51 \%$ equivalent to a biomass flow of $50 \mathrm{ton} / \mathrm{h}$. Saha and Cotta [49] used the same biomass with simultaneous sequential pre-saccharification and fermentation treatments, obtaining $11 \mathrm{~g} / \mathrm{L}$ of bioethanol after 53 hours of fermentation. Singh, et al. [70], treated the rice husk with microwave-assisted alkali, resulting in $0.36 \mathrm{~g}$ bioethanol/g using Scheffersomyces stipitis and $0.4 \mathrm{~g}$ bioethanol/g, with S. cerevisiae.

In the present study, it is observed a total of 983 thousand tons of lignocellulosic bioethanol with a productivity of 0.176 ton of bioethanol/ton of rice waste, equivalent to 629 thousand toe, representing $25 \%$ more than what was generated in 2008 with 504 thousand toe.

\section{Bioethanol from banana biomass}

In the attempt to define the most suitable conditions for enzymatic hydrolysis and fermentation of agricultural banana waste (pseudostems and rachis), Guerrero, et al. [71] determined that using a method of simultaneous saccharification and fermentation with 72 hours of reaction, were by extrapolating the results at an industrial level is possible to obtain $112 \mathrm{~L}$ of bioethanol for every dry ton of pseudostems. On the other hand, Santa-Maria, et al. [72] evaluated the bioconversion of different lignocellulosic residues generated in banana cultivation, thus determining that it is possible to obtain $320 \mathrm{~L}$ of bioethanol/ton of waste. In the present study, for the year 2018 a theoretical potential yield of $133.58 \mathrm{~L}$ of bioethanol/ton of biomass was obtained. With these results, it follows that banana biomass represents an important potential to produce fuel bioethanol.

\section{Bioethanol from yellow corn biomass}

Theoretically, considering the composition of the corn stubble [56], it is possible to calculate the stoichiometric yield of bioethanol generation from this type of waste, obtaining 246.1 L of bioethanol per tons of waste [73], in this regard in this study the yield of bioethanol from corn stubble was 217.05 L of bioethanol/ton of waste by 2015 . With the objective of improving the yield of bioethanol generation from corncobs, Brar, et al. [57] subjected the sample to a fermentation process with a staggered hybrid approach based 
on the use of acid and enzymatic hydrolysate in a single container, increasing the productivity of the process by $2.4 \%$.

\section{Bioethanol from oil palm biomass}

Researchers from countries where the oil palm crop has a higher incidence and representativeness have shown interest in the production of bioethanol from oil palm biomass.

Ishola, et al. [74] used different pre-treatments to empty fruit clusters to produce bioethanol. The study resulted in a bioethanol production of $4.1 \mathrm{~g} / \mathrm{L}$ without prior treatment after 96 hours of fermentation; 62.8\% yield after 48 hours of simultaneous saccharification and fermentation (FSS) with a combined physical-chemical pre-treatment and $89.4 \%$ after FSS with a phosphoric acid pre-treatment. Srimachai, et al. [75] worked with oil palm leaf biomass for the production of bioethanol with different pre-treatments, obtaining a maximum bioethanol yield of $0.32 \mathrm{~g}$ of bioethanol $/ \mathrm{g}$ of glucose and a yield of $62.75 \%$ of theoretical bioethanol production, with pre-treatment of impregnation with microwave-assisted water. As mentioned, the use of oil palm biomass for the potential generation of bioethanol has a broad field of research at an international level, so the continuous growth of its production, ensure that Peru could generate a feasible bioethanol production capacity, as efficient as other agricultural biomass.

\section{Bioethanol from asparagus biomass}

Regarding studies using asparagus peel for bioethanol production, Bardales Vásquez, et al. [40] subjected the asparagus peel to physical-chemical pre-treatments with subsequent extraction of total reducing sugars and fermentation with the Candida Utilis Major strain. The highest value in bioethanol production was $2.04 \%(20.4 \mathrm{~mL}$ of bioethanol), from a concentration of $7 \mathrm{~g} / \mathrm{L}$ of total reducing sugars. Xiaohua, et al. [65] developed a study that considers asparagus stem as lignocellulosic raw material for anaerobic digestion, which can be used, in addition to animal feed, for the production of bioenergy, such as bioethanol, biogas or biohydrogen.

\section{E. Energy potential of bioethanol}

Although the total biomass available in Peru, represents only $0.01032 \%$ of the total biomass worldwide [76], the equivalent energy potential when converting said biomass into bioethanol is enough to cover approximately $9.15 \%$ of the national energy demand. As is expected, in the next years, renewable energy from bio combustibles obtained from renewable sources will be highly demanded. Therefore, the calculation of the energy potential of the different options as energy sources has been explored. From algae [77], non-food raw materials [78], plant, animal and even human waste [79] have been evaluated as sources of energy generation.

The theoretical calorific energy potential was calculated using (8), while the potential for electricity generation of bioethanol, using (9), the results presented correspond to the bioethanol production of the last studied year of each type of biomass.

The total theoretical potential of lignocellulosic bioethanol that could have been obtained from the selected biomass amounts to a total of 3.51 million tons of bioethanol (Table III), of which it was observed that the highest amount was coming from sugarcane biomass with 1.14 million tons, followed by bioethanol from rice and banana, with 0.98 and 0.85 million tons respectively. Therefore, the sugarcane biomass had the greatest energy and electricity generation potential and may have generated 701.1 ktoe/year. By considering all the energy potential, this would be able to cover $2.19 \%$ of energy consumption in the country.

Regarding the total energy contained in bioethanol, a total potential of $90.62 \mathrm{TJ}$ of energy per year equivalent to 2.16 Mtoe was obtained, with the capacity to replace approximately $9.11 \%$ of the national energy demand in 2014 (23.7 Mtoe), from the per capita demand of energy registered for that year of 0.76769 toe/per capita [80] and the total national population for the same year of 31 million people [81]. Under these same parameters, with the potential for generating electricity obtained, it is possible to replace $0.02 \%$ of the national electricity demand, with a per capita consumption for 2014 of $1307,511 \mathrm{kWh}$ [82].

\section{F. Carbon dioxide (CO2) emission savings}

The energy potential of the bioethanol produced from lignocellulosic biomass could replace by $32 \%$ the energy demand of the transportation sector in the country, demonstrating the importance of promoting this type of studies towards reducing the use of liquid fuels focused on the transport sector.

Likewise, it was possible to calculate the tons of $\mathrm{CO}_{2}$, which would cease to be emitted to the environment (Table IV) from the equivalent tons of petroleum from the bioethanol obtained, using equation (10). The results showed that it is possible to reduce approximately $12.1 \mathrm{Mton}$ of $\mathrm{CO}_{2}$ emissions to the environment, which would represent $19.86 \%$ of total $\mathrm{CO}_{2}$ emissions by 2014 at national level, $0.64 \%$ at Latin America level, and $0.03 \%$ worldwide, according to World Bank figures [83]. Based on the results presented in Table IV, an efficient power generation capacity is expected from the conversion of lignocellulosic bioethanol, however, it is necessary to put more effort into the development of new technologies that enhance the energy industry from of biomass, taking into account certain factors that allow this development, such as: security of medium and long-term lignocellulosic energy supply, economic viability of converting biomass into bioethanol, environmental impacts and benefits in the economic and social sector of the country [84], likewise, the efficiency of the use of each technology and type of biomass must be taken into account [85]. 
TABLE III

\begin{tabular}{|c|c|c|c|c|}
\hline Biomass type & $\begin{array}{c}\text { Total bioEtOH } \\
\text { (x 10 }{ }^{3} \text { kton/year) }\end{array}$ & 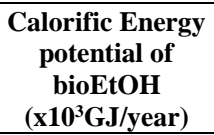 & $\begin{array}{c}\text { Total energy in } \\
\text { ton of oil } \\
\text { equivalent }\left(\mathbf{x} 10^{5}\right. \\
\text { toe/year) }\end{array}$ & $\begin{array}{c}\text { Electric energy } \\
\text { potential of } \\
\text { bioEtOH } \\
\left(\mathbf{x 1 0}^{6} \mathrm{kWh} / \text { year }\right)\end{array}$ \\
\hline Biomass from sugarcane & 1.14 & 29.4 & 7.01 & 2.85 \\
\hline Biomass from rice & 0.98 & 25.38 & 6.06 & 2.47 \\
\hline Biomass from banana & 0.85 & 21.91 & 5.23 & 2.13 \\
\hline Biomass from yellow corn & 0.15 & 3.78 & 0.90 & 0.37 \\
\hline Biomass from oil palm & 0.15 & 3.81 & 0.91 & 0.37 \\
\hline Biomass from asparagus & 0.25 & 6.39 & 1.53 & 0.62 \\
\hline Total lignocellulosic biomass & 3.51 & 90.62 & 21.64 & 8.81 \\
\hline
\end{tabular}

TABLE IV

$\mathrm{CO}_{2}$ EMISSIONS THAT WOULD CEASE TO BE EMITTED INTO THE ENVIRONMENT (TON/YEAR)

\begin{tabular}{|l|c|c|c|}
\hline \multicolumn{1}{|c|}{ Biomass type } & $\begin{array}{c}\mathbf{C O}_{\mathbf{2}} \text { emissions by } \\
\text { petroleum } \\
\text { combustion (x10 }\end{array}$ & $\begin{array}{c}\mathbf{C O}_{\mathbf{2}} \text { emissions by } \\
\text { bioEtOH combustion } \\
(\mathbf{x 1 0} \text { ton) }\end{array}$ & $\begin{array}{c}\text { Reduced CO } \\
\text { emission }(\mathbf{x 1 0}\end{array}$ \\
\hline Biomass trom ton $)$ \\
\hline Biomass from rice & 50.06 & 10.87 & 39.19 \\
\hline Biomass from banana & 43.28 & 9.40 & 33.88 \\
\hline Biomass from yellow corn & 37.36 & 8.11 & 29.25 \\
\hline Biomass from oil palm & 6.44 & 1.40 & 5.04 \\
\hline Biomass from asparagus & 6.50 & 1.41 & 5.09 \\
\hline Total lignocellulosic biomass & 10.91 & 2.37 & 8.54 \\
\hline
\end{tabular}

\section{CONCLUSIONS}

The result of this study estimates that the bioethanol potential that could be produced from biomass from sugarcane, rice, corn, banana, yellow corn, oil palm and asparagus residues could have reached $\sim 3.5$ million tons of bioethanol in 2018. With the amount of bioethanol produced from the aforementioned biomass, an energy potential of 2.2 million toe/year was obtained, capable of supplying $9.11 \%$ of the national energy demand, likewise, an electric generation potential of $8.81 \mathrm{GWh} /$ year would be ensured, managing to cover $0.02 \%$ of the national electricity demand; and a reduction in $\mathrm{CO}_{2}$ emissions to the environment of $19.86 \%$ taking advantage of the total energy potential of bioethanol obtained.

With these results and from the consulted bibliography, it is possible to position Peru in the way of being a country with potential production of renewable energy using lignocellulosic waste that is currently discarded. In addition, is recommended exploring regarding the energy use of lignocellulosic biomass as an alternative for the development of biofuels.

\section{REFERENCES}

L. J. Cseke, G. K. Podila, A. Kirakosyan, and B. Kaufman, "Plants as sources of energy," in Recent Advances in Plant Biotechnology, ed: Springer, 2009, pp. 163-210.

[2] CDIAC. CO2 emissions from liquid fuel consumption (\% of total) - Latin America \& Caribbean, Peru, World [Online]. Available:

https://data.worldbank.org/indicator/EN.ATM.CO2E.LF.ZS?en $\mathrm{d}=2014$ \&locations $=$ ZJ-PE-1W\&start $=2003$

[3] T. H. Oh, S. Y. Pang, and S. C. Chua, "Energy policy and alternative energy in Malaysia: issues and challenger for sustainable growth.," Renewable and Sustainable Energy Reviews, vol. 14, pp. 1241 - 1252, 2010.

[4] EIA. (2018, 5/09/2018). Energy Information Administration: Today in Energy. Available: https://www.eia.gov/todayinenergy/detail.php?id=32912

[5] M. F. Demirbas, M. Balat, and H. Balat, "Potential contribution of biomass to the sustainable energy development," Energy Conversion and Management, vol. 50, pp. 1746 - 17602009.

[6] V. Menon and M. Rao, "Trends in bioconversion of lignocellulose: biofuels, platform chemicals \& biorefinery concept," Progress in energy and combustion science, vol. 38, pp. 522-550, 2012

[7] M. Balat and H. Balat, "Recent trends in global production and utilization of bio-ethanol fuel," Applied energy, vol. 86, pp. 22732282, 2009.

[8] C. S. Goh, K. T. Tan, K. T. Lee, and S. Bhatia, "Bio-ethanol from lignocellulose: status, perspectives and challenges in Malaysia," Bioresource technology, vol. 101, pp. 4834-4841, 2010.

[9] I. Kurnia, A. Yoshida, N. Chaihad, A. Bayu, Y. Kasai, A. Abudula, et al., "Hydrolysis of cellulose and woody biomass over sustainable weak-acid carbon catalysts from alkaline lignin," Fuel Processing Technology, vol. 196, p. 106175, 2019.

[10] S. Brethauer and C. E. Wyman, "Continuous hydrolysis and fermentation for cellulosic ethanol production," Bioresource technology, vol. 101, pp. 4862-4874, 2010.

[11] R. Raele, J.-M. Gama-Boaventura, A.-A. Fischmann, and G. Sarturi, "Scenarios for the second generation ethanol in Brazil," Technological Forecasting \& Social Change, vol. 87, pp. 205223, 2014.

[12] PERUPETRO. Estadística Petrolera [Online]. Available: www.perupetro.com.pe

[13] A. V. Cordano. (2005, La demanda agregada de combustibles líquidos en el Perú. Osinergmin. Available: http://www.osinergmin.gob.pe/

[14] F. C. Gutierrez Naveda, J. L. Caro Jara, R. Mendoza Sosa, and J. Campos Gavilán, "Balance Nacional de Energía 2016," Ministerio de Energía y Minas, Lima2016.

[15] SIEA. Sistema Integrado de Estadística Agraria (SIEA), Informe de Seguimiento Agroeconómico (ISA) [Online]. Available: http://siea.minagri.gob.pe/siea/ 
[16] RFA. (2016, Enero 1). Fuel Ethanol Trade Measurements and Conversions. Available: https://ethanolrfa.org/wpcontent/uploads/2015/12/Fuel-Ethanol-Trade-Measurementsand-Conversions_RFA.pdf

[17] A. Budí Orduña, "Estimación del potencial energético de la biomasa residual agrícola y análisis de aprovechamiento en los municipios de la comarca del Alto Palancia," 2016.

[18] A. C. Cardona and T. O. Sánchez, "Energy consumption analysis of integrated flowsheets for production of fuel ethanol from lignocellulosic biomass," Energy, vol. 31, pp. 2447-2459, 2006.

[19] S. A. F. Henao, J. D. Mosquera, and J. C. Mosquera, "Análisis de emisiones de $\mathrm{CO} 2$ para diferentes combustibles en la población de taxis en Pereira y Dosquebradas," Scientia et technica, vol. 2, 2010.

[20] MINAGRI. Serie de estadísticas de Producción Agrícola (SEPA) [Online]. Available: http://frenteweb.minagri.gob.pe/sisca/?mod=consulta_cult

[21] INEI. Compendio Estadítico Perú 2015. Producción departamental del sector agrario [Online].

[22] C. A. Romero, E. Urrego Vargas, and E. Castro Ballvé, "El Banano Peruano "Producto estrella de exportación". Tendencias endencias de la producción y el comercio e la producción y el comercio del banano en el mercado del banano en el mercado

internacional y nacional.," MINAGRI-DGPA, Lima2014.

[23] C. A. Romero, "Situación comercial del banano orgánico en el mercado europeo.," MINAGRI-DGPA, Lima2018.

[24] W. Koo. (2019, Enero 23). Plátano - Banano Perú Exportación 2018 Diciembre. AGRODATAPERU. Available: https://www.agrodataperu.com/2019/01/platano-banano-peruexportacion-2018-diciembre.html

[25] MINAGRI, "Plan Estratégico de la Cadena Productiva del Maíz Amarillo Duro Avícola y Porcícola.," DGCA, Lima2003.

[26] INIA. (2018, Marzo 21). Programa Nacional de Maíz y Trigo. Available: http://www.inia.gob.pe/pn-maiz-y-trigo/

[27] JUNPALMA, "Estadística de la Palma aceitera al 2014," Junta Nacional de Palma Aceitera del Perú (JUNPALMA PERÚ), Lima2016.

[28] Agrodata. Exportaciones Agropecuarias [Online]. Available: https://www.agrodataperu.com/exportaciones

[29] InstitutoCrecer. (2018, Octubre 15) Escenarios de riesgo y oportunidades para el agro peruano. Gestión. Available: https://gestion.pe/blog/innovacion-sinergias-y-

crecimiento/2018/10/escenarios-de-riesgo-y-oportunidadespara-el-agro-peruano.html?ref=gesr

[30] OCDE/FAO. (2018, Perspectivas agrícolas OCDE-FAO 20182027.

[31] H. S. A. Khalil, M. S. Alwani, and A. K. M. Omar, "Chemical composition, anatomy, lignin distribution, and cell wall structure of Malaysian plant waste fibers," BioResources, vol. 1, pp. 220232, 2006.

[32] A. B. Guerrero, P. L. Aguado, J. Sánchez, and M. D. Curt, "GISBased Assessment of Banana Residual Biomass Potential for Ethanol Production and Power Generation: A Case Study," Waste Biomass Valor vol. 7, pp. 405-415, 2016.

[33] R. M. Jingura and R. Matengaifa, "The potential for energy production from crop residues in Zimbabwe," Biomass and Bioenergy, vol. 32, pp. 1287-1292, 2008.

[34] D. A. Schneuer Finlay, "Estudio Exploratorio para la Producción de Bioetanol y Co-Productos de Biorefinería, a Partir de Rastrojos de Maíz," 2010.

[35] H. Faiguenbaum, "Manejo del rastrojo de maíz y ventajas de su incorporación al suelo," Semillas Tuniche. Información técnica, Chile2009.

[36] C. Echeverria, G. Bazan, J. Sanchez-Gonzalez, L. Lescano, S Pagador, and G. Linares, "Pre-treatment by Acidification and Freezing on Corncob Polymers and its Enzymatic Hydrolysis," Asian Journal of Scientific Research, vol. 11, pp. 222-231, 2018.

[37] H. B. Aditiya, W. T. Chong, T. M. Mahlia, A. H. Sebayang, M. A. Berawi, and H. Nur, "Second generation bioethanol potential from selected Malaysia's biodiversity biomasses: A review," Waste Management, vol. 47, pp. 46-61, 2016.

[38] A. T. Yuliansyah, S. Kumagai, T. Hirajima, and K. Sasaki, "Potential recovery of sugar-derivative compounds from hydrothermal treatment of oil palm empty fruit bunch," IOP Conference Series: Materials Science and Engineering, vol. 736, p. $022048,2020 / 03 / 052020$.

[39] M. A. Callacná Custodio, Z. E. León Gallardo, and G. Mendoza Ordoñez, "Características nutritivas del ensilaje mixto de maíz chala (zea mays 1.) y broza de esparrago (asparragus officinalis) con melaza - urea e inóculo bacterial como suplemento alimenticio para cabras en manejo semi extensivo," SCIÉNDO Ciencia Para el Desarrollo, vol. 17, 2014.

[40] C. B. Bardales Vásquez, C. A. León Torres, J. Mostacero León, J. Arellano Barragan, C. Nomberto Rodriguez, M. Salazar Castillo, et al., "Producción de bioetanol del desecho lignocelulósico "peladilla" de Asparagus officinalis L. "espárrago" por Candida utilis var. Major. CECT 1430," UCVSCIENTIA, vol. 3, pp. 205-213, 2015.

[41] J. C. León Carrasco. (2018) Producción mundial de aceite de palma alcanzó las 64.8 millones de toneladas en 2017. AGRARIA.PE Agencia Agraria de noticias. Available: http://agraria.pe/noticias/produccion-mundial-de-aceite-depalma-alcanzo-las-648-millon-16021

[42] J. A. Chacón Chauca, "Propuesta técnica para el incremento de procesamiento de caña de azúcar a $300 \mathrm{~T} / \mathrm{H}$ del trapiche de un ingenio azucarero en el norte del Perú," 2014.

[43] M. Young, O. Almazán, L. González, C. De Armas, N. Fernandez, N. La Serna, et al., "La industria de los derivados de caña de azúcar. Instituto Cubano de Investigaciones de los derivados de caña de azúcar (ICIDCA)," in Capítulo IV. Bagazo, J. Valdéz Montero, Ed., ed La Habana: Editorial CientíficoTécnica, 1986, p. 117.

[44] H. Ramírez- Cathí, A. C. Salcedo Martínez, F. Briones Encina, F. Lucero Magaña, A. Cárdenas Lara, C. Marcof Álvarez, et al., "Rendimiento, caracterización morfológica y bromatológica de la punta de caña de azúcar en la Huasteca Potosina, México," Revista Cubana de Ciencia Agrícola, vol. 48, pp. 411 - 415, 2014.

[45] A. Curbelo, G. Bárbara, G. Moreda, and A. Valdes, "Generación de electricidad a partir de bagazo en Cuba," FAO, Cuba2002.

[46] T. S. León-Martínez, D. Dopíco-Ramírez, O. Triana-Hernández, and M. Medina-Estevez, "Paja de la caña de azúcar. Sus usos en la actualidad," Instituto Cubano de Investigaciones de los Derivados de la Caña de Azúcar, vol. 47, pp. 13 - 22, 2013.

[47] O. J. Jaramillo Pineda, M. Á. Gómez García, and J. Fontalvo Alzate, "Removal of ethanolic fermentation inhibitors using polydimethylsiloxane (PDMS) membranes by pervaporation," Ion, vol. 25, pp. 51 - 59, 2012.

[48] U. Kumar and M. Bandyopadhyay, "Sorption of cadmium from aqueous solution using pretreated rice husk," Bioresource Technology, vol. 97, pp. 104 - 109, 2006.

[49] B. C. Saha and M. A. Cotta, "Lime pretreatment, enzymatic saccharification and fermentation of rice hulls to ethanol," Biomass Bioenergy, vol. 32, pp. 971 - 977, 2008.

[50] M. Hashim, "Present status and problems in biomass utilization for electricity generation in Malaysia biomass," Asia Workshop Tokyo, Japan 2005.

[51] K. Poh and H. Kong, "Renewable energy in Malaysia: a policy analysis," Energy for Sustainable Development vol. 6, pp. 31 39, 2002.

[52] P. Binod, R. Sindhu, R. Singhania, S. Vikram, L. Devi, and S. Nagalakshmi, "Bioethanol production from rice straw: an overview," Bioresource Technology, vol. 101, pp. 4767 - 4774, 2010.

[53] E. R. Kasper Fernandes, C. Marangoni, O. Souza, and N. Sellin, "Thermochemical characterization of banana leaves as a potential energy source," Energy Conversion and Management, vol. 75, pp. 603-608, 2013.

$1^{\text {th }}$ LACCEI International Multi-Conference for Engineering, Education, and Technology: "Engineering, Integration, and Alliances for a Sustainable 
[54] L. Oliveira, Cordeiro, E. N., T. D. V., and S. I. C., A. J., "Chemical composition of different morphological parts from "Dwarf Cavendish" banana plant and their potential as a nonwood renewable source of natural products," Industrial Crops and Products, vol. 26, pp. 163-172 2007.

[55] J. Gabhane, S. P. William, A. Gadhe, R. Rath, A. N. Vaidya, and S. Wate, "Pretreatment of banana agricultural waste for bioethanol production: individual and interactive effects of acid and alkali pretreatments with autoclaving, microwave heating and ultrasonication," Waste Manag, vol. 34, pp. 498-503 2014.

[56] C. Ravikumar, S. P. Kumar, S. K. Subhashni, P. V. Tejaswini, and V. Varshini, "Microwave assisted fast pyrolysis of corn cob, corn stover, saw dust and rice straw: Experimental investigation on bio-oil yield and high heating values," Sustainable Materials and Technologies, vol. 11, pp. 19 - 27, 2017.

[57] K. K. Brar, S. Kaur, and B. S. Chadha, "A novel staggered hybrid SSF approach for efficient conversion of cellulose/hemicellulosic fractions of corncob into ethanol," Renewable Energy, vol. 98, pp. 1 - 7, 2016.

[58] G. S. Wang, J. W. Lee, J. Y. Zhu, and T. W. Jeffries, "Dilute acid pretreatment of corncob for efficient sugar production," Appl Biochem Biotechnol, vol. 163, pp. 658-668, 2011.

[59] S. H. Kong, S. K. Loh, R. T. Bachmann, S. A. Rahim, and J. Salimon, "Biochar from oil palm biomass: A review of its potential and challenges," Renewable and Sustainable Energy Reviews, vol. 39, pp. 729-739, 2014.

[60] T. L. Kelly-Yong, K. T. Lee, A. R. Mohamed, and S. Bhatia, "Potential of hydrogen from oil palm biomass as a source of renewable energy worldwide," Energy Policy, vol. 35, pp. 5692$5701,2007$.

[61] S. K. Loh, Oil palm biomass energy resource data: Malaysian Palm Oil Board, MPOB., 2012.

[62] S. Yusoff, "Renewable energy from palm oil - innovation on effective utilization of waste," Journal of Cleaner Production, vol. 14, pp. 87-93, 2006.

[63] S. Prasertsan and P. Prasertsan, "Biomass residues from palm oil mills in Thailand: an overview on quantity and potential usage," Biomass and Bioenergy, vol. 11, pp. 387-395, 1996.

[64] E. G. Macías Rodríguez, "Aplicación de celulasas o xilanasas para mejorar en la digestión ruminal in vitro en tres resíduos de cosecha," Doctorado en Ciencia Animal, Escuela de Posgrado, Universidad Nacional Agraria La Molina, Lima, 2015.

[65] C. Xiaohua, G. Yu, Z. Xuefei, and Y. Zhang, "Asparagus stem as a new lignocellulosic biomass feedstock for anaerobic digestion: Increasing hydrolysis rate, methane production and biodegradability by alkaline pretreatment," Bioresource Technology, vol. 164, pp. 78-85, 2014.

[66] L. M. Zumalacárregui-De Cárdenas, O. Pérez-Ones, P. A Rodríguez-Ramos, and G. Lombardi, "Potencialidades del bagazo para la obtención de etanol frente a la generación de electricidad," Ingeniería, investigación y tecnología, vol. 16, pp. 407-418, 2015.

[67] S. Raghavi, R. Sindhu, P. Binod, E. Gnansounou, and A. Pandey, "Development of a novel sequential pretreatment strategy for the production of bioethanol from sugarcane trash " Bioresource Technology, vol. 199, pp. 202 - 2010, 2016.

[68] Y. d. C. Velásquez Riascos and J. E. López, "Estudio de prefactibilidad para el diseño de una planta de etanol a partir de residuos de cosecha de caña de azúcar," Mutis, vol. 6, pp. 74 - 81, 2016.

[69] V. Capdevila, V. Kafarov, C. Gely, and A. Pagano, "Simulación del proceso fermentativo para la obtención de bioetanol a partir de residuos de arroz," Avances en Ciencias e Ingeniería, vol. 6, pp. 11-21, 2015.

[70] A. Singh, S. Bajar, and N. R. Bishnoi, "Enzymatic hydrolysis of microwave alkali pretreated rice husk for ethanol production by Saccharomyces cerevisiae, Scheffersomyces stipitis and their coculture," Fuel, vol. 116, pp. 699 - 702, 2014.

[71] A. B. Guerrero, I. Ballesteros, and M. Ballesteros, "The potential of agricultural banana waste for bioethanol production," Fuel, vol. 213, pp. 176-185, 2018.

[72] M. Santa-Maria, Ruiz-Colorado, A. A., G. Cruz, and T. Jeoh, "Assessing the feasibility of biofuel production from lignocellulosic banana waste in rural agricultural communities in peru and colombia.," BioEnergy Research, vol. 6, pp. 1000-1011, 2013.

[73] M. J. Arellano H., M. Avilés S., and C. Zúñiga C., "Producción de bioetanol y lignina a partir de rastrojos de maíz," Drpartamento de Ingeniería Química. Facultad de Ciencias físicas y matemáticas, Universidad de Chile, 2015.

[74] M. M. Ishola, Isroi, and M. J. Taherzadeh, "Effect of fungal and phosphoric acid pretreatment on ethanol production from oil palm empty fruit bunches (OPEFB)," Bioresource Technology, vol. 165, pp. 9-12, 2014.

[75] T. Srimachai, V. Thonglimp, and S. O-Thong, "Ethanol and Methane Production from Oil Palm Frond by Two Stage SSF," Energy Procedia, vol. 52, pp. 352-361, 2014.

[76] J. M. O. Martínez, M. J. N. Alvarez, P. M. Secades, I. B. Perdices, and M. B. Perdices, "Proceso de sacarificación y fermentación simultáneas para la conversión de la fracción celulósica del residuo de la extracción del aceite de oliva en etanol," Grasas y aceites, vol. 53, pp. 282-288, 2002.

[77] M. A. Borowitzka and N. R. Moheimani, Algae for biofuels and energy vol. 5: Springer, 2013.

[78] A. S. Ramadhas, S. Jayaraj, and C. Muraleedharan, "Biodiesel production from high FFA rubber seed oil," Fuel, vol. 84, pp. 335-340, 2005.

[79] G. A. Linares-Lujan, C. Echeverria-Perez, and T. CespedesAguilar, "Energy potential of the rural area of "La Libertad" department (Peru) produced by biogas obtained from human waste," Revista Tecnología en Marcha, vol. 30, pp. 108-117, 2017.

[80] OECD/IEA. Energy use ( $\mathrm{kg}$ of oil equivalent per capita) [Online]. Available:

https://databank.worldbank.org/reports.aspx? source $=2 \&$ type $=\mathrm{m}$ etadata\&series=EG.USE.PCAP.KG.OE

[81] INEI, "11 de Julio día mundial de la población," Insitutto Nacional de Estadística e Informática (inei), Lima2014.

[82] OECD/IEA. Electric power consumption (kWh per capita) [Online]. Available: https://data.worldbank.org/indicator/EG.USE.ELEC.KH.PC

[83] CDIAC. CO2 emissions (kt) - Latin America \& Caribbean, Peru, World [Online]. Available: https://datos.bancomundial.org/indicator/EN.ATM.CO2E.KT?e nd $=2015 \&$ locations $=$ ZJ - PE $-1 \mathrm{~W} \&$ start $=1960 \&$ view $=$ chart

[84] Y. Tye, K. T. Lee, W. Wan-Nadiah, and L. C. Peng, "Secondgeneration bioethanol as a sustainable energy source in Malaysia transportation sector: Status, potential and future prospects," Renewable and Sustainable Energy Reviews, vol. 15, pp. 45214536, 2011.

[85] A. Dammert Lira and R. García Carpio, "Economía de la Energía," in Capítulo 2: Consumo total de energía, ed Lima: Fondo Editorial Pontificia Universidad Católica del Perú, 2017, pp. 47-61.

$1^{\text {th }}$ LACCEI International Multi-Conference for Engineering, Education, and Technology: "Engineering, Integration, and Alliances for a Sustainable Development" "Hemispheric Cooperation for Competitiveness and Prosperity on a Knowledge-Based Economy", 29-31 July 2020, Buenos Aires, Argentina. 10 